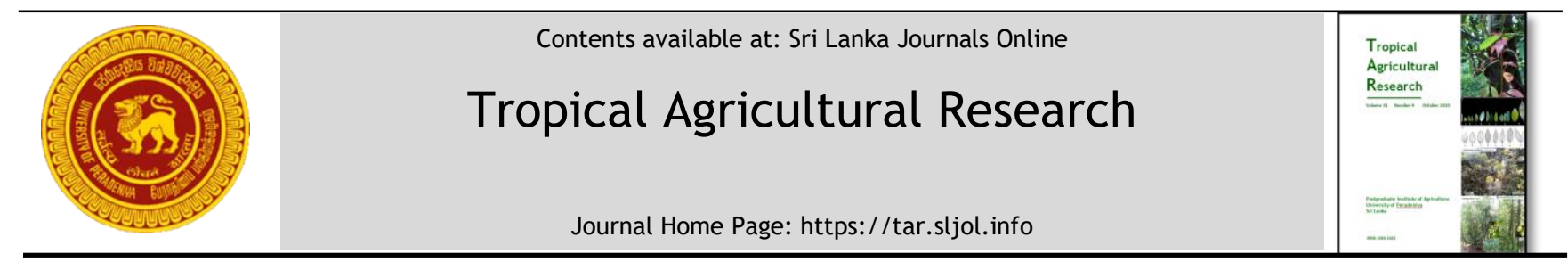

\title{
Relationship Among NAGase Enzyme Activity, CMT Score and Somatic Cell Count in Milk of Crossbred Dairy Cows with Sub-Clinical Mastitis in North-Western Province of Sri Lanka
}

\author{
R. Rahularaj ${ }^{1}$, R.M.C. Deshapriya ${ }^{2 *}$ and R.M.S.B.K. Ranasinghe ${ }^{3}$ \\ 1 Postgraduate Institute of Agriculture, University of Peradeniya, Peradeniya, Sri Lanka. \\ ${ }^{2}$ Department of Animal Science, Faculty of Agriculture, University of Peradeniya, Sri Lanka. \\ ${ }^{3}$ Department of Basic Veterinary Sciences, Faculty of Veterinary Medicine and Animal Science, University of Peradeniya, \\ Sri Lanka.
}

\section{ARTICLE INFO}

\section{Article history:}

Received: 02 October 2019

Accepted: 15 November 2019

Revised version received: 27 July 2020

Available online: 1 October 2020

\section{Keywords:}

Crossbred cows

NAGase

Somatic cell count

Sub-clinical mastitis

\section{Citation:}

Rahularaj, R., Deshapriya, R.M.C. and

Ranasinghe, R.M.S.B.K. (2020).

Relationship Among NAGase Enzyme

Activity, CMT Score and Somatic Cell

Count in Milk of Crossbred Dairy Cows

with Sub-Clinical Mastitis in North-

Western Province of Sri Lanka. Tropical

Agricultural Research, 31(4): 26-32.

DOI: http://doi.org/10.4038/tar.v31i4.8418

Rahularaj, R. id

https://orcid.org/0000-0002-9038-0443

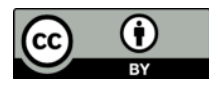

\section{ABSTRACT}

The assay procedure for $\mathrm{N}$-acetyl- $\beta$-D-glucosaminidase (NAGase) was considered to be the most reliable, simple, and rapid enzymatic method for estimating the severity of mammary tissue damage. This study was carried out to assess the relationship of NAGase enzyme activity, California mastitis test score (CMTS) and somatic cell counts (SCC) in milk and the influence of breed, parity and age of the cow on NAGase activity. The results showed that prevalence of sub-clinical mastitis (SCM) was $74.5 \%$ $(41 / 55)$ in the population of cows tested. The isolated pathogens were Staphylococcus spp. (34\%, 14/41), Escherichia coli $(34 \%, 14 / 41)$ and Streptococcus spp. $(32 \%, 13 / 41)$. The SCC showed a significant $(\mathrm{p}<0.05)$ positive correlation with the activity of NAGase (R2= 0.796) and CMTS (R2=0.709). A significant correlation was observed between the NAGase activity and SCC in SCM positive milk, where the correlation was stronger $(\mathrm{R} 2=0.748)$ in the former than in the latter. The parity $(R 2=0.843)$ and age $(R 2=0.758)$ of the cow also showed $a$ significant $(p<0.05)$ positive correlation with enzyme activity. The mean SCC and enzyme activity of different crossbreds of the study population did not show a significant correlation, but mean values of SCC and enzyme activity were higher when an animal was phenotypically more related to European breeds (779$1848 \mathrm{x} 103 \mathrm{SCC} / \mathrm{ml} ; 0.64 \quad-0.89 \mu \mathrm{mole} / \mathrm{min} / \mathrm{ml}$ ) than tropical breeds $(427-534 \times 103 \quad \mathrm{SCC} / \mathrm{ml} ; \quad 0.26-0.43$ $\mu \mathrm{mole} / \mathrm{min} / \mathrm{ml}$ ). It could be concluded that, the prevalence of SCM in crossbred cows in North-Western Province of Sri Lanka is considerably high. The determination of NAGase enzyme activity in milk could be used as a method for early detection of SCM more accurately than CMTS and SCC.

*Corresponding author : cdeshapriya@pdn.ac. 


\section{INTRODUCTION}

Sub-clinical mastitis (SCM) adversely affects milk production, milk quality and herd health (Schultz et al., 1978). Several studies conducted in the country have shown that the high prevalence of sub-clinical mastitis among lactating cows is noticeably contributing to the poor milk quality (Deshapriya et al., 2007; Gunawardena et al., 2014; Abeygunawardena et al., 2017; Sanotharan and Deshapriya, 2018; Deshapriya et al., 2019; Rahularaj et al., 2019).

The pathogens which cause SCM, mainly bacteria, damage the udder tissues leading to pathological changes in the udder, thus increasing the bacteria population in milk. Further, the milk quality is also affected due to the enzymes secreted from bacteria and the enzymes released into milk through the damaged epithelium of mammary tissues. These enzymes not only decrease the quality of raw milk but also reduce the keeping quality of processed milk products (Barbano et al., 1991). In response to the infection, udder tissue exerts an inflammatory response during which further leaking of blood components and infiltration of somatic cells into the milk take place. Studies have shown that somatic cells and somatic cell count (SCC) are good indicators of mammary infection (Barbano et al., 1991; Marcus et al., 1994; Ynte et al., 2003; Sharma et al., 2011; Li et al., 2014). The SCC is estimated directly by microscopic analysis or electronic counter method and using a number of other indirect methods. One of the conventional indirect methods is the California Mastitis Test (CMT) (Schalm and Noorlander, 1957). However, CMT is relatively an expensive and a subjective method and also might result false positive or false negative results (Viguier et al., 2009). The direct cell counting using cell counters are more accurate but the cost per sample is comparatively high. Hence, it is essential to develop rapid, sensitive and cost effective methods to detect SCM for the Sri Lanka dairy sector. A number of enzyme assays have been developed to quantify the extent of udder tissue damage that occurs during intra-mammary infections. The assay procedure for $N$-acetyl- $\beta$-D-glucosaminidase
(NAGase) has been considered to be the most reliable, simple, and rapid enzymatic method (Kitchen, 1976). Therefore, this study was carried out with an aim of finding the relationship of SCC, CMTS and NAGase activity tests that are used to determine subclinical mastitis, and of selecting the most suitable method for early detection of SCM in crossbred cows.

\section{MATERIALS AND METHODS}

A total of 55 crossbred milking cows (Friesian, Ayrshire, Jersey crosses with Sahiwal, Sindhi or Sahiwal crosses with Lankan cattle) were screened for SCM using CMT. Any cow showing a California Mastitis Test Score (CMTS) of above 2 at least in one quarter was classified as SCM positive.

A sample of milk $(20 \mathrm{ml})$ was collected aseptically from each positive quarter into sterilized glass bottles and sub-samples were taken for microbiological analysis and enzyme assay. The SCC was taken from the rest of the sample by using Lactoscan Somatic Cell Counter (Model- LQD kit4, Bulgaria) at cow side. The sub-samples were transported under cool conditions for further analysis to the laboratory of the Department of Animal Science, Faculty of Agriculture, University of Peradeniya, Sri Lanka, and samples were cultured on nutrient agar enriched with 7\% sheep blood within six hours of collection. The bacteriological and biochemical analyses were carried out according to the methods described by Jang et al. (1978).

The enzyme assay was carried out according to Kitchen (1976) where, citrate buffer $(200 \mathrm{mM})$ and $\rho$-nitophenyl-N-Acetyl- $\beta$-Dglucosaminide (Sigma Aldrich N9376 CAS:3459-18-5) substrate were used. A sample of $0.2 \mathrm{ml}$ of milk and $0.3 \mathrm{ml}$ of substrate were taken in to $5 \mathrm{ml}$ stoppered polypropylene tube, mixed well and incubated at $50^{\circ} \mathrm{C}$ for 15 minutes. The reaction was stopped by adding $1 \mathrm{ml}$ of $1 \mathrm{M}$ glycine adjusted to $\mathrm{pH} 10.5$ with $\mathrm{NaOH}$, and then $1 \mathrm{ml}$ of chloroform was added to the tubes, shaken vigorously for 5 seconds before centrifuging at $2000 \mathrm{~g}$ for 10 minutes. The top aqueous layer was separated using a Pasteur pipette and absorbance was determined at 
410 or $515 \mathrm{~nm}$ wave length using a V1000 digital VIS Spectrophotometer (Xi'an HEB Biotechnology Co. Ltd., China).

The correlation among SCC, CMTS and enzyme activity were analyzed using linear regression at $95 \%$ confidence interval. The comparison of means was carried out using one-way ANOVA (SPSS 19th version, IBM 2007).

\section{RESULTS AND DISCUSSION}

The results of both CMT and microbiological analysis showed that the prevalence of SCM of the study sample of crossbred cows was $74.5 \% \quad(41 / 55) . \quad$ The biochemical characterization of specific pathogens revealed that there were three types of bacteria, namely Staphylococcus spp. (34\%, 14/41), Escherichia coli $(34 \%, 14 / 41)$ and

a

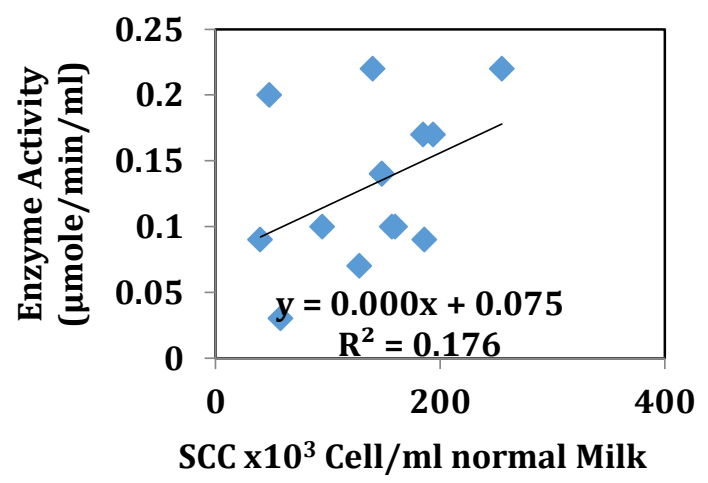

Streptococcus spp. (32\%, 13/41). Staphylococcus spp. is considered to be a contagious type of pathogen while Escherichia coli and Streptococcus spp. are considered to be environmental type of pathogens (Shaheen et al., 2016).

The SCC showed significant $(\mathrm{P}<0.05)$ positive correlations with NAGase enzyme activity $\left(\mathrm{R}^{2}=0.796\right.$ and CMTS $\left(\mathrm{R}^{2}=0.709\right)$. A strong correlation was observed between enzyme activity and SCC in SCM positive milk compared to normal milk as illustrated in Figures $1 \mathrm{a}$ and $1 \mathrm{~b}$. Similar observations have been reported by Chagunda et al. (2006) and Hovinen et al. (2016). According to Kitchen et al. (1978) the enzyme NAGase is released from both white blood cells and epithelial cells, and its concentration and activity are low in healthy quarters (Pyorala et al., 2011) and increase with SCM condition.

b

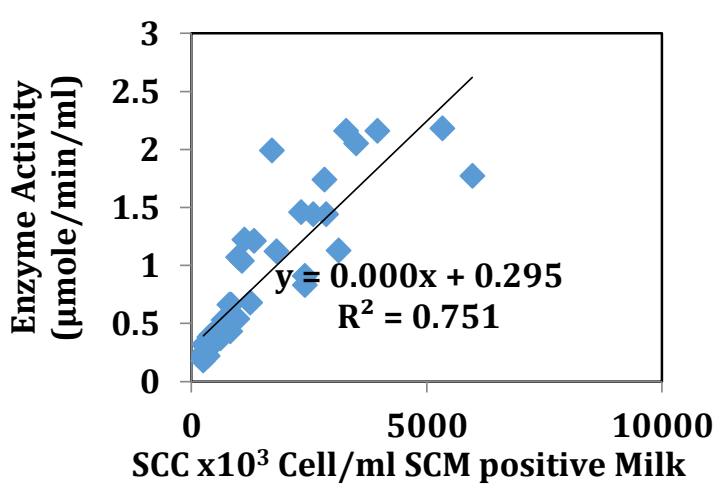

Figure 1: Relationship between Enzyme Activity and SCC in (a) normal and (b) SCM positive milk.

Figures 2 and 3 show the relationship of SCC with NAGase enzyme activity and CMTS. The correlation between the enzyme activity and SCC was stronger $\left(R^{2}=0.796 ; \mathrm{p}<0.05\right)$ than that between SCC and CMTS. CMT is not sensitive at low somatic cell count for detection of subclinical infections (Kitchen, 1981). Parity and age of SCM positive cows showed a strong $(\mathrm{P}<0.05)$ positive correlation with enzyme activity, with $\mathrm{R}^{2}=0.843$ and $\mathrm{R}^{2}=$
0.758 , respectively. When the age of a cow increases, the occurrence of SCM also increases because the teat canal of older animals is more dilated and permanently open due to years of repeated milking (Sudhan and Sharma., 2010). Higher the parity, more the chances to be positive for SCM because teat canals become tender (Alemu et al., 2013). 


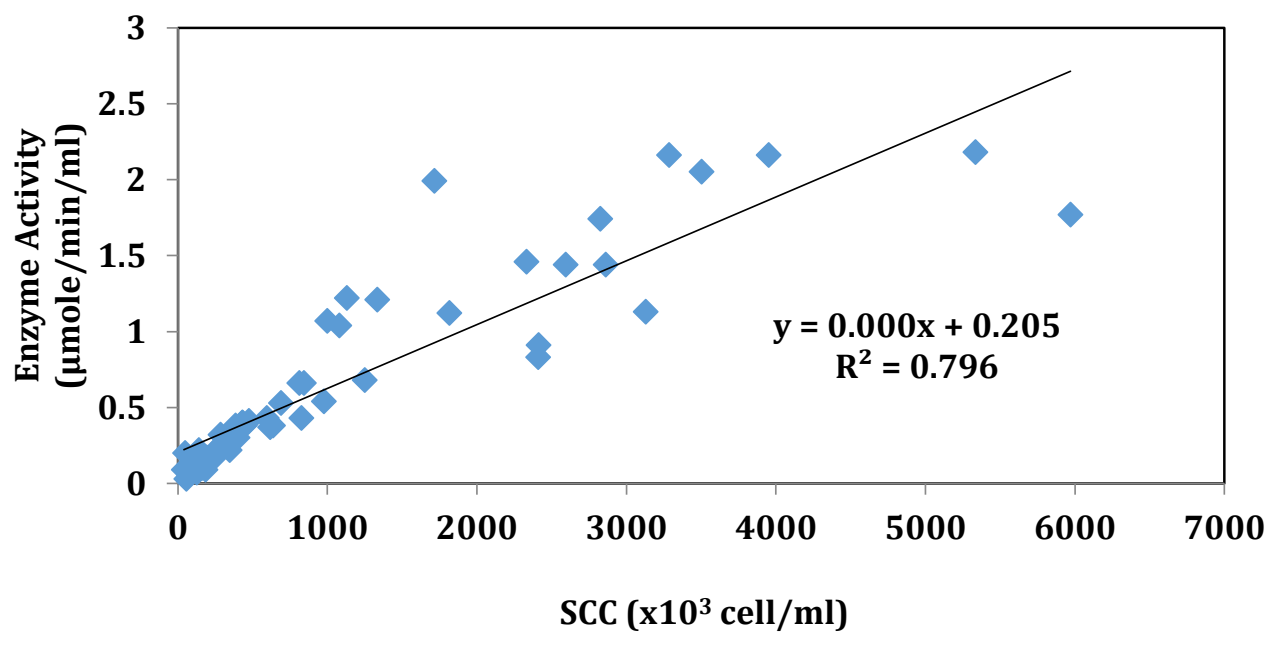

Figure 2: Relationship between Enzyme activity and Somatic Cell Counts.

Even though the correlation between mean SCC and enzyme activity of different crossbreds was not significant, the mean values of SCC and enzyme activity were comparatively high when an animal phenotypically resembled more of European breeds (Friesian, Ayrshire, Jersey) (779-1848 $\left.\mathrm{x} 10^{3} \mathrm{SCC} / \mathrm{ml} ; 0.64-0.89 \mu \mathrm{mole} / \mathrm{min} / \mathrm{ml}\right)$ than towards tropical crosses $\left(427-534 \times 10^{3}\right.$ $\mathrm{SCC} / \mathrm{ml} ; 0.26-0.43 \mu \mathrm{mole} / \mathrm{min} / \mathrm{ml})$. This could be due to the fact that the European crosses are high yielding animals, and thus they are more susceptible to mastitis than tropical breeds (Sudhan and Sharma, 2010). Shittu et al. (2012) stated that teats of high yielding European breeds are anatomically weak to resist the disease causing bacteria compared to tropical breeds and the latter has a narrow teat canal or a firmer sphincter at the end of the teat tip.

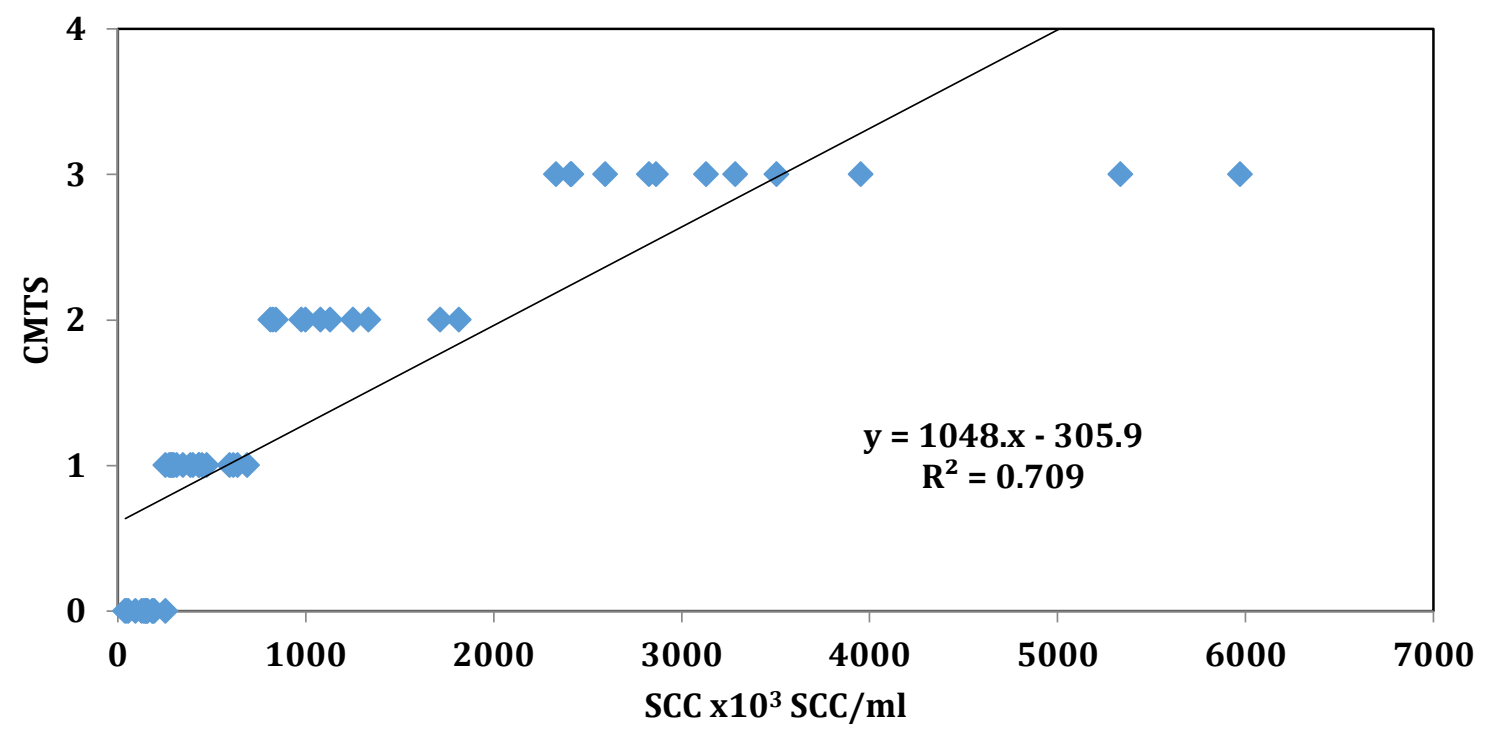

Figure 3: Relationship between California Mastitis Test Score_and Somatic Cell Counts. 
Adequate supply of irrigation water is one of the most limiting factors determining the yield of paddy and thus the nutrient removal from the soil. Further, irrigation water is a source of $\mathrm{K}$ supply for the paddy crop (Buresh et al., 2019). Majority of farmers in Polonnaruwa and Kurunegala districts are relying on irrigation water from major irrigation systems (command area is greater than 80 ha) in which the irrigation water supply is more reliable during the dry yala season. But, in Anuradhapura district equal proportions of farmers depend on major and minor irrigation facilities. Minor irrigation systems depend on village tanks which are often abandoned during yala season and shortages of adequate supply of water are experienced in the maha season. Thus, this heterogeneity of the supply of irrigation water also has an influence on the variability of soil available $\mathrm{K}$ content.

The oxidation and reduction processes governed by the alternate flooding and drying of paddy soils directly influence the $P$ availability (Ponnamperuma, 1972). Thus, the spatial-temporal variation of oxidationreduction process resulted by the heterogeneity of the availability of irrigation water could contribute for the

\section{REFERENCES}

Abeygunawardena, D.I., Ranasinghe, R.M.S.B.K. and Deshapriya, R.M.C. (2017). Hygienic practices and quality of raw milk produced in a small scale dairy farming area in Sri Lanka. International Journal of Scientific and Research Publications. 7, 72-77.

Alemu, S., Tvamiru, F., Almaw, G. and Tsega, A. (2013). Study on bovine mastitis and its effect on chemical composition of milk in and around Gondartawn, Ethiopia. Journal of Veterinary Medicine and Animal Health. 5, 215221.

Barbano, D.M., Rasmussen, R.R. and Lynch, J.M. (1991). Influence of milk Somatic Cell Count and milk age on Cheese spatial variability of soil P levels observed in study areas.

\section{CONCLUSIONS}

The prevalence of sub-clinical mastitis in crossbred lactating cows in North-Western Province of Sri Lanka was considerably high (74.5\%). The most common pathogens found were Staphylococus spp., E. coli and Streptococcus spp. Even though the California mastitis test is available through milk collecting agencies, routine checking for sub-clinical mastitis has not happened mainly due to the high cost. The assay of NAGase activity in sub-clinical mastitis positive milk is an accurate method for assessing the mammary tissue damage compared to the somatic cell counts and California mastitis test score. Therefore, the determination of NAGase activity could be suggested as an accurate method for early diagnosis of sub-clinical mastitis.

\section{ACKNOWLEDGEMENT}

The authors wish to acknowledge the financial support given by National Research Council of Sri Lanka (Grant No. 2015-087) and also the kind cooperation given by the farmers for the study.

Yield. Journal of Dairy Research. 48, 437-445.

Chagunda, M.G.G., Larsen, T., Bjerring, M. and Ingvart, K.L. (2006). L-lactate dehydrogenase and N-acetyl- $b$-Dglucosaminidase activities in bovine milk as indicators of non-specific mastitis. Journal of Dairy Research. 7, 431-440.

Deshapriya, R.M.C, Rahularaj R. and Ranasinghe, R.M.S.B.K. (2019). Mastitis, Somatic Cell Count and Milk Quality: an overview. Sri Lanka Veterinary Journal. 66(1), 1-12.

Deshapriya, R.M.C., Silva, K.F.S.T. and Wilbey, R.A. (2007). Investigation of suitable pasteurization conditions for raw 
milk in Sri Lanka. Sri Lanka Veterinary Journal. 53, 1-6.

Gunawardena, S., Thilakarathne, D., Abegunawardana, I.S., Abeynayake, P., Robertson, C. and Stephen, C. (2014). Risk factors for bovine mastitis in the Central Province of Sri Lanka. Tropical Animal Health and Production. 46, 1105-1112.

Hovinen, M., Simojoki, H., Poso, R., Suolaniemi, J., Kalmus, P., Suojala, L. and Pyorala, S. (2016). N-acetyl - $\beta$-Dglucosaminidase activity in cow milk as an indicator of mastitis. Journal of Dairy Research. 83(02), 219-227.

Jang, S.S., Biberstein, E.L. and Hrish, D.C. (1978). A diagnostic manual of veterinary clinical bacteriology and mycology (First Edition). Davis: Microbiological Diagnostic Laboratory, Veterinary Medical Teaching Hospital, University of California.

Kitchen, B.J. (1976). Enzymic Methods for Estimation of the Somatic Cell Count in Bovine milk. Journal of Dairy Research. 43, 251-258.

Kitchen, B.J. (1981). Review of the progress of Dairy Science: Bovine mastitis: milkcompositional changes and related diagnostic tests. Journal of Dairy Research. 48, 167-188.

Kitchen, B.J., Middleton, G. and Samlon, M. (1978). Bovine millk N-acetyl- $\beta$-Dglucosaminidase and its significant in the detection of abnormal udder secretions. Journal of Dairy Research. $45,15-20$.

Kehrli, M.E. and Shuster, D.E. (1994). Factors Affecting Milk Somatic Cells and Their Role in Health of the Bovine Mammary Gland. Journal of Dairy Science. 77, 619-627.

Li, N., Richoux, R. Boutinaud, M., Martin, P. and Gagnaire, V. (2014). Role of somatic cells on dairy processes and products: a review. Dairy Science and Technology. 94, 517-538.

Pyorala, S., Hovinen, M., Simojoki, H., Fitzpatrick, J., Eckersall, P.D. and Orro, T. (2011). Acute phase proteins in milk in naturally acquired bovine mastitis caused by different pathogens. Veterinary Record. 168(20), 535-535.

Rahularaj, R., Deshapriya, R.M.C. and Ranasinghe, R.M.S.B.K. (2019). Influence of bovine sub-clinical mastitis and associated risk factors on calving interval in a population of crossbred lactating cows in Sri Lanka. Tropical Animal Health and Production. 51(8): 2413-2419.

Sanotharan, N and Deshapriya, R.M.C. (2018). A preliminary investigation on milk quality in Ampara District of Sri Lanka. International Journal of Scientific Research. 8: 7.

Schalm, O.W. and Noorlander, D.O. (1957). Experiments and observations leading to development of the California Mastitis Test. Journal of the American Veterinary Medicine Association. 130, 199-204.

Schultz, L.H., Broom, R.W., Jasper, D.E., Berger, R.W.M., Natwke, R.P., Philpot, W.N., Smith, W. and Thompson, P.D. (1978). Current concepts of bovine mastitis. $2^{\text {nd }}$ Ed. NMC, Washington, D.C. USA. 69.

Shaheen, M., Tantary, H.A. and Nabi, S.U. (2016). A Treatise on Bovine Mastitis: Disease and Disease Economics, Etiological Basis, Risk Factors, Impact on Human Health, Therapeutic Management, Prevention and Control Strategy. Journal of Advances in Dairy Research. 4, 150.

Sharma, N., Singh, N.K. and Bhadwal, M.S. (2011). Relationship of Somatic Cell Count and Mastitis: An Overview. 
Asian-Australian Journal of Animal Science. 24(3), 429-438.

Shittu, A., Abdullahi, J., Jibril, A., Mohammed, A. and Fasina, F. (2012). Subclinical mastitis and associated risk factors on lactating cows in the Sarvannah Region of Nigeria. BioMed Central Veterinary Research. 8, 134.

Sudhan, N.A. and Sharma, N. (2010). Mastitis, an important production disease of dairy animals. Farm management and diseases. Serva Manav Vikas Samiti's Dairy Year Book, Rajendra Nagar, Sahibabad, Ghaziabad, India, 47-65.
Viguier, C., Arora, S., Gilmartin, N., Welbeck, K. and O'kennedy, R. (2009). Mastitis detection; current trends and future perspectives. Trends

Biotechnology. 27(8), 486-93.

Ynte H.S., Wilson, D.J., Welcome, F., GarrisonTikofsky, L. and Gonzalez, R.N. (2003). Monitoring udder health and milk quality using somatic cell counts. Veterinary Research. 34, 579-596. DOI: $10.1051 /$ vetres:2003028 